\title{
KENAKALAN PADA REMAJA ANDIKPAS (ANAK DIDIK LAPAS): PENGARUH KOMUNIKASI ORANG TUA ATAU SELF-ESTEEM?
}

\author{
Ismayanti Pratiwi ${ }^{1 *}$, Dwi Hastuti ${ }^{1}$ \\ ${ }^{1}$ Departemen Ilmu Keluarga dan Konsumen, Fakultas Ekologi Manusia, Institut Pertanian Bogor, Bogor 16680, \\ Indonesia \\ *)Email: ismayantipratiwi30@gmail.com
}

\begin{abstract}
Abstrak
Penelitian ini bertujuan untuk menganalisis hubungan komunikasi orang tua-remaja, self-esteem, dan kenakalan remaja yang menjadi andikpas (anak didik lapas) di LPKA. Penelitian dilakukan di LPKA yang berlokasi di Bandung dan melibatkan 63 orang remaja laki-laki andikpas dengan usia 15-18 tahun yang dipilih dengan menggunakan simple random sampling. Kenakalan remaja diukur menggunakan kuesioner Adoption Self Report Delinquency Scale (ASRDS) yang diadaptasi dari Carroll et al. (1996). Instrumen self-esteem menggunakan kuesioner yang diadaptasi dari Rosenberg (1965). Instrumen komunikasi orang tua-remaja menggunakan kuesioner Parent-Adolescent Communication Scale yang diadaptasi dari Barnes dan Olson (1982). Data dianalisis dengan analisis deskriptif dan uji Korelasi Pearson. Hasil analisis korelasi Pearson menemukan adanya hubungan signifikan positif antara komunikasi orang tua-remaja dimensi keterbukaan dengan self-esteem andikpas remaja. Hubungan signifikan negatif ditemukan antara komunikasi orang tua-remaja dimensi permasalahan dengan self-esteem andikpas remaja. Selanjutnya, hasil penelitian juga menemukan terdapat hubungan signifikan negatif antara komunikasi orang tua-remaja dimensi keterbukaan dan self-esteem dengan kenakalan andikpas remaja. Sementara itu, ditemukan adanya hubungan signifikan negatif antara self-esteem dengan kenakalan andikpas remaja.
\end{abstract}

Kata kunci: anak didik lapas (andikpas), kenakalan remaja, komunikasi orang tua-remaja, Lembaga Pembinaan Khusus Anak (LPKA), self-esteem

\section{Delinquency of Juvenile Prisoners: Caused by Parent-Adolescent Communication or Self-Esteem?}

\begin{abstract}
This study aimed to analyze the relationship of parent-adolescent communication, self-esteem, and delinquency of juvenile prisoners. The study was conducted at the juvenile prison in Bandung and involved 63 boys with age 15-18 years old; who were selected using simple random sampling. Juvenile delinquency was measured using the Adoption Self Report Delinquency Scale (ASRDS) questionnaire by Carroll et al. (1996). The self-esteem instrument used a questionnaire adapted from Rosenberg (1965). The parent-adolescent communication instrument used the Parent-Adolescent Communication Scale questionnaire adapted from Barnes and Olson (1982). Data were analyzed by descriptive analysis and Pearson correlation. Pearson correlation analysis found that there was a positive significant relationship between openness dimension of parent-adolescent communication with the self-esteem of juvenile prisoners. A significant negative relationship was found between problem dimension of parent-adolescent communication with the self-esteem of juvenile prisoners. Furthermore, the study also found a significant negative relationship between openness dimension of parent-adolescent communication and self-esteem with delinquency of juvenile prisoners. There was a significant negative relationship between self-esteem with delinquency of juvenile prisoners.
\end{abstract}

Keyword: juvenile delinquency, juvenile prison, juvenile prisoners, parent-adolescent communication, self-esteem

\section{PENDAHULUAN}

Kenakalan remaja merupakan perilaku yang melanggar norma yang dilakukan oleh seseorang yang belum beranjak dewasa, yang berusia dibawah 18 tahun. Kenakalan yang dilakukan berjenjang dari hal yang serius seperti pembunuhan sampai hal kecil seperti membolos atau mencuri (Cobb, 2001). Kenakalan remaja mengacu pada rentang yang luas, mulai dari tingkah laku yang tidak dapat diterima secara sosial sampai pelanggaran terhadap tindakan kriminal (Santrock, 2003). Sarwono (2012) membatasi pengertian kenakalan remaja sebagai penyimpangan terhadap norma-norma yang 
berlaku di masyarakat (norma agama, etika, dan peraturan sekolah). Kenakalan remaja meliputi pencurian, pelanggaran peraturan di jalan raya, alkohol dan obat terlarang, perusakan, pelanggaran peraturan di sekolah, dan tingkat yang mengganggu masyarakat (Carroll et al., 1996). Penelitian Puspitawati (2006) menemukan bahwa tingkat kenakalan yang dilakukan remaja di Kota Bogor meliputi kenakalan umum seperti membolos, menyelewengkan uang SPP, minggat dari rumah, dan kenakalan kriminal seperti perkelahian, merusak kendaraan umum, penganiayaan, judi, membawa senjata tajam, minum minuman keras, dan konsumsi NAPZA, yang pada beberapa kasus membawa remaja berhadapan dengan hukum.

Kenakalan remaja biasanya berlanjut pada tindakan kriminal. Remaja yang melakukan tindak kriminal cenderung mengalami kegagalan dalam akademik, memiliki selfesteem yang rendah, lebih menyukai kekerasan fisik untuk menyampaikan ketidaksetujuannya, kontrol diri yang rendah, dan hubungan keluarga yang buruk (Cobb, 2001). Data dari situs yang dipublikasikan oleh Direktorat Jenderal Pemasyarakatan (Ditjenpas, 2015) Kementrian Hukum \& HAM menyatakan bahwa tercatat 1.373 tahanan anak pada bulan November 2015, dimana Provinsi Jawa Barat sebagai penyumbang angka tertinggi yaitu 188 orang. Pada bulan Juli 2015 terdapat peningkatan jumlah tahanan, jumlah peningkatan mencapai 50 persen dari angka sebelumnya yaitu 80 pada bulan Juni dan 161 pada bulan Juli.

Kenakalan yang dilakukan remaja menurut Gunarsa dan Gunarsa (2004) dipengaruhi oleh tiga faktor, yaitu faktor pribadi, keluarga, dan lingkungan sosial. Faktor pribadi dibagi menjadi dua yakni faktor pribadi yang melekat by given dan tidak dapat diubah seperti jenis kelamin, usia, dan urutan kelahiran, serta faktor pribadi yang didapatkan dari pengetahuan, pengalaman dan keterampilan sehingga dapat ditingkatkan yaitu kecerdasan emosi dan self-esteem. Faktor keluarga memengaruhi kenakalan remaja melalui hubungan orang tua dan anak.

Remaja laki-laki berpotensi lebih besar untuk melakukan kenakalan remaja dibandingkan dengan anak perempuan (Puspitawati, 2006; Christopher et al., 2007). Fakta menunjukan bahwa angka tertinggi tindak kenakalan ada pada usia 15-19 tahun (Kartono, 2008). Hal ini menunjukan bahwa jenis kelamin dan umur berhubungan dengan tingkat kenakalan remaja. Selain karakteristik remaja, faktor individu lain yang berpengaruh terhadap kenakalan remaja adalah self-esteem. Selfesteem merupakan penilaian atau persepsi diri yang dilakukan oleh seorang individu terhadap dirinya atas penghargaan, penerimaan, dan perlakuan orang lain terhadap dirinya (Coopersmith, 1967). Self-esteem memiliki banyak aspek dan berkembang dalam konteks pengembangan pengertian seseorang terhadap identitas diri. Self-esteem adalah gabungan nilai diri yang dirasakan seseorang, bagaimana seseorang merasakan dirinya layak atas kebahagiaan, kesehatan dan kesejahteraan, rasa hormat, persahabatan, cinta, prestasi, dan kesuksesan (Youngs, 1991).

Rosenberg (1965) membagi self-esteem menjadi dua komponen secara global, yaitu sikap positif dan sikap negatif. Komponen tersebut digunakan untuk menjelaskan gambaran atau penilaian positif seseorang terhadap dirinya serta evaluasi global seseorang mengenai dirinya. Puspitawati (2006) menjelaskan bahwa self-esteem memiliki pengaruh negatif terhadap tingkat kenakalan. Donnellan et al. (2005) menyatakan bahwa self-esteem yang rendah berkaitan dengan kenakalan remaja. Wan (2012) dalam penelitiannya menjelaskan bahwa self-esteem tidak memiliki hubungan dengan tingkat kenakalan. Selanjutnya, Xiao, $\mathrm{Li}$, dan Stanton (2011) menyatakan bahwa komunikasi yang dilakukan orang tua terhadap anak memiliki pengaruh positif terhadap selfesteem anak.

Selain faktor individu, faktor keluarga juga memiliki pengaruh terhadap kenakalan remaja. Penelitian Ngale (2009) menyebutkan bahwa tingkat kenakalan remaja berkaitan dengan besar keluarga, pengasuhan permisif, dan status ekonomi orang tua. Mayoritas anak yang melakukan kenakalan berasal dari strata sosial ekonomi terendah masyarakat. Sekitar dua-pertiga dari remaja yang terlibat kenakalan berasal dari keluarga yang tinggal satu atap dengan orang tuanya, akan tetapi tidak memiliki komunikasi yang baik. Komunikasi orang tua dengan remaja harus berkualitas baik agar orang tua dapat memberikan pendidikan dan menanamkan nilai kepada remajanya. Buruknya kualitas komunikasi orang tua dengan remaja dapat menjadi faktor penyebab penyimpangan perilaku remaja (Gunawan, 2013). Remaja dengan komunikasi yang buruk dengan orang tuanya akan lebih rentan terlibat dalam kenakalan remaja. Odgers et al. (2012) dalam penelitiannya 
membuktikan bahwa praktek pengasuhan dan dukungan orang tua, seperti pemantauan orang tua dan kehangatan ibu serta komunikasi keluarga dapat menurunkan tingkat kenakalan remaja.

Komunikasi orang tua-remaja berkaitan dengan aspek kehidupan remaja. Ketika remaja merasa bahwa mereka dapat mengomunikasikan sudut pandangnya kepada orang tua akan mengakibatkan kepuasan hidup dan penghargaan pada diri remaja sehingga remaja dapat terhindar dari perilaku negatif seperti kenakalan remaja (Jackson et al., 1998). Puspitawati (2006) menyatakan bahwa komunikasi orang tua-remaja yang tinggi dapat menurunkan tingkat kenakalan remaja. Hasil penelitian Putra (2013) menunjukkan bahwa komunikasi yang intensif antara orang tua dan anak remaja akan menciptakan hubungan interpersonal yang baik sehingga mencegah remaja melakukan hal-hal negatif. Hasil penelitian Berlianti et al. (2016) menunjukkan bahwa komunikasi orang tua-remaja yang tidak berlangsung dengan baik akan meningkatkan perilaku kekerasan pada anak.

Kenakalan remaja yang semakin meningkat tidak dapat dilepaskan dari kualitas individu dan lingkungan tempat remaja tumbuh. Selain itu, dukungan dari orang tua, seperti pemantauan orang tua, kehangatan ibu, dan komunikasi orang tua-remaja bisa menjadi efek bertahan dari kekurangan lingkungan yang beresiko terhadap perilaku antisosial pada anak (Odgers et al., 2012). Firdanianty et al. (2016) dalam hasil penelitiannya menunjukkan bahwa komunikasi orang tua dan anak laki-laki lebih rendah dibandingkan dengan anak perempuan.

Tujuan penelitian ini adalah menganalisis hubungan komunikasi orang tua-remaja, dan self-esteem, terhadap kenakalan pada remaja di LPKA. Penelitian ini diharapkan dapat memberikan manfaat untuk memberikan informasi kepada orang tua tentang pengaruh komunikasi orang tua-remaja dan self-esteem terhadap kenakalan remaja. Dengan demikian, penelitian ini dapat dijadikan bahan pertimbangan bagi orang tua dalam melakukan komunikasi sebagai salah satu aspek penting dalam praktek pengasuhan positif. Bagi LPKA hasil penelitian ini diharapkan dapat dijadikan landasan untuk membuat program bagi remaja di LPKA. Bagi penelitian selanjutnya, diharapkan penelitian ini dapat berguna untuk pengembangan ilmu di bidang ilmu keluarga dan perkembangan anak.

\section{METODE}

Penelitian ini menggunakan desain crosssectional study. Penelitian ini mengunakan metode restrospektif, yaitu peneliti ingin menggali informasi yang sudah terjadi di masa lampau (sebelum masuk LPKA) berkaitan dengan self-esteem, komunikasi orang tuaremaja, dan tingkat kenakalan. Data dikumpulkan dengan metode wawancara dengan bantuan kuesioner. Penelitian dilakukan di Lembaga Pembinaan Khusus Anak Kelas II Bandung yang dipilih secara purposive karena lokasi ini merupakan lembaga pembinaan khusus anak yang memiliki peserta terbanyak di Provinsi Jawa Barat.

Populasi penelitian ini adalah seluruh andikpas (anak didik lapas) di Lembaga Pembinaan Khusus Anak (LPKA) Kelas II Bandung. Kriteria contoh dalam penelitian ini adalah andikpas remaja berusia 12 hingga 18 tahun dengan orang tua lengkap, akan tetapi karena keterbatasan data terkait orang tua contoh, maka kriteria contoh hanya usia saja. Pengambilan contoh dilakukan dari populasi peserta LPKA Kelas II Bandung dengan menggunakan metode simple random sampling yaitu contoh yang diambil sedemikian rupa sehingga tiap unit penelitian dari populasi memiliki kesempatan yang sama untuk dipilih sebagai contoh. Contoh penelitian dihitung menggunakan formula Slovin, dengan menggunakan rumus di atas dan margin error $0,1(10,0 \%)$ dan didapatkan jumlah contoh sebanyak 63 orang dari 157 populasi remaja di LPKA.

Data yang dikumpulkan terdiri atas karakteristik remaja, karakteristik keluarga, komunikasi orang tua-remaja, self-esteem, dan tingkat kenakalan pada remaja di LPKA. Data karakteristik remaja terdiri atas usia, pendidikan, dan keterangan drop out atau tidak. Sementara itu, data karakteristik keluarga yang dikumpulkan adalah besar keluarga, pekerjaan orang tua, dan aset yang dimiliki keluarga.

Kenakalan remaja diukur menggunakan kuesioner Adoption Self Report Delinquency Scale $(A S R D S)$ yang diadaptasi dari Carroll et al. (1996) dengan jumlah 35 pertanyaan menggunakan skala Likert 3 poin (1=tidak pernah, 2=kadang-kadang, 3= sering) dengan Cronbach's Alpha 0,875. Instrumen selfesteem menggunakan kuesioner yang diadaptasi dari Rosenberg (1965) dengan jumlah 10 pertanyaan dengan skala Likert 
(1=sangat tidak sesuai, 2=tidak sesuai, 3=sesuai, 4=sangat sesuai) dan memiliki Cronbach's Alpha 0,564. Instrumen komunikasi orang tua-remaja menggunakan kuesioner Parent-Adolescent Communication Scale yang diadaptasi dari Barnes dan Olson (1982) dengan jumlah 20 pertanyaan yang meliputi keterbukaan dan permasalahan orang tua-remaja dengan skala Likert ( $1=$ sangat tidak sesuai, 2=tidak sesuai, 3=sesuai, 4=sangat sesuai) dengan Cronbach's Alpha 0,749. Selanjutnya, skor variabel-variabel yang diteliti dikategorikan dengan menggunakan cut-off point dari skor yang telah dibuat indeks $(0,0$ 100,0) dengan mengkategorikan menjadi "rendah" jika skor indeks kurang dari rata-rata dan "tinggi“ jika skor indeks lebih dari sama dengan rata-rata.

Sebelum proses pengumpulan data, dilakukan proses persiapan terdiri penyusunan rencana penelitian, membuat surat persetujuan keterlibatan dalam penelitian kepada LPKA kelas II Bandung melalui Kementrian Hukum dan HAM Provinsi Jawa Barat, dan survei awal untuk pemilihan responden yang sesuai dengan kriteria.

Data yang terkumpul selanjutnya diolah melalui proses editing, coding, scoring, entry, cleaning, analyzing, dan interpretasi data. Pengolahan data menggunakan perangkat lunak Microsoft Office Excel dan analisis data dilakukan dengan menggunakan program Statistical Package for Social Science (SPSS). Analisis data yang digunakan pada setiap variabel yang akan disesuaikan dengan tujuan penelitian. Identifikasi karakteristik remaja, karakteristik keluarga, komunikasi orangtuaremaja, self-esteem, dan kenakalan remaja menggunakan analisis statistika deskriptif seperti jumlah, persentase, nilai rataan, standar deviasi, nilai minimun, dan nilai maksimum. Selanjutnya, analisis hubungan antara karakteristik contoh, karakteristik keluarga, komunikasi orang tua-remaja, selfesteem dengan tingkat kenakalan remaja menggunakan uji korelasi.

\section{HASIL}

\section{Karakteritik LPKA Kelas II Bandung}

Penelitian dilakukan di Lembaga Pembinaan Khusus Anak kelas (LPKA) kelas II Bandung. LPKA merupakan lembaga peradilan pidana terhadap anak yang disesuaikan dengan Undang-Undang Sistem Peadilan Pidana anak No. 11 Tahun 2012. Berlakunya UU SPA Nomor 11 tahun 2012 ini mengakibatkan sistem peradilan yang lebih mengayomi dan melindungi anak. Sistem peradilan yang lebih mengayomi anak dibutuhkan karena anak memiliki kebutuhan khusus yang berbeda dengan orang dewasa. Di LPKA, anak dapat melanjutkan pendidikan formal (SD, SMP, SMA, SMK), diberikan keterampilan hidup, kegiatan seni, dan olahraga sesuai dengan minat anak. Pembinaan nonformal juga diberikan pada peserta LPKA untuk menambah keterampilan hidup, menyalurkan minat anak, serta mengembalikan nilai-nilai kebaikan dalam diri anak. Kegiatan pembinaan meliputi bidang kerohanian, kesadaran hukum, jasmani, kesadaran berbangsa dan bernegara, pembinaan pertanian, peternakan, kesenian, dan teknologi informasi.

LPKA Kelas II Bandung diresmikan pada Tahun 2013. Sebelumnya anak yang berhadapan dengan hukum ditempatkan dengan lapas yang sama dengan narapidana dewasa. Di bulan Juni 2016 andikpas (anak didik lapas) di LPKA berjumlah 183 orang, meningkat dari bulan sebelumnya yaitu 174 orang. Pada saat penelitian dilakukan (Maret 2016), jumlah andikpas adalah 179 orang. Hal ini menunjukan bahwa terjadi peningkatan jumlah andikpas dari Maret-Juni 2016.

\section{Karakteristik Anak}

Seluruh andikpas remaja berjenis kelamin lakilaki. Usia andikpas remaja berkisar antara 1518 tahun dengan rata-rata usia 17 tahun. Tingkat pendidikan andikpas remaja berkisar antara tidak tamat SD/Sederajat hingga tamat SMA/Sederajat. Rata-rata lama pendidikan andikpas remaja adalah 8,5 tahun. Berdasarkan sebaran aktifitas sebelum terlibat dalam kasus, lebih dari setengah total andikpas remaja $(58,7 \%)$ sudah bekerja karena tidak meneruskan jenjang pendidikan formal, dan sisanya $(41,3 \%)$ adalah pelajar. Andikpas remaja terlibat dalam kasus yang beragam meliputi pelanggaran ketertiban, pencurian, perampokan, narkotika, asusila, perlindungan anak, dan pembunuhan. Kasus pelanggaran terhadap perlindungan anak merupakan kasus yang paling banyak dilakukan oleh andikpas remaja dengan sebaran 34,9 persen, diikuti dengan kasus pelanggaran ketertiban 19,0 persen.

\section{Karakteristik Keluarga}

Berdasarkan besar keluarga inti, sebesar 35,5 persen keluarga andikpas remaja berada pada kategori keluarga kecil dengan jumlah anggota keluarga 1 sampai 4 orang. Sebanyak 50,8 
persen keluarga andikpas remaja termasuk keluarga sedang dan 12,7 persen keluarga besar, dengan rata-rata jumlah anggota keluarga yaitu 5,3 orang. Pekerjaan orang tua dikategorikan menjadi pekerjaan formal dan nonformal. Berdasarkan hasil penelitian, mayoritas (82,5\%) ayah andikpas remaja bekerja pada sektor nonformal. Mayoritas Ibu andikpas remaja $(77,8 \%)$ beraktivitas sebagai ibu rumah tangga. Status pernikahan orang tua dikategorikan menjadi menikah, bercerai, dan menikah lagi. Hasil penelitian menunjukan bahwa 79,4 persen orang tua andikpas remaja memiliki status menikah, 9,5 persen bercerai, dan 11,1 menikah lagi.

Andikpas remaja tidak mengetahui pendapatan orang tua mereka. Oleh karena itu, penelitian ini menggunakan kepemilikan aset untuk menggambarkan status sosial ekonomi andikpas remaja. Sebagian besar keluarga andikpas remaja $(69,3 \%)$ memiliki rumah sendiri, 6,3 persen menumpang pada saudara dan 25,4 persen mengontrak. Seluruh keluarga andikpas remaja memiliki televisi, hal ini menandakan bahwa televisi merupakan kebutuhan bagi keluarga sebagai sarana hiburan. Hanya sebagian kecil andikpas remaja yang memiliki mobil $(19,40 \%)$ sedangkan hampir seluruh andikpas remaja $(92,0 \%)$ memiliki motor.

\section{Komunikasi Orang Tua-Remaja, Self- Esteem, dan Kenakalan Remaja}

Hasil penelitian menunjukan bahwa sebagian besar $(79,4 \%)$ memiliki keterbukaan yang rendah dan 20,6 persen andikpas remaja memiliki tingkat keterbukaan yang tinggi. Selanjutnya, 52,4 persen andikpas remaja memiliki kedalaman permasalahan yang rendah. Secara keseluruhan, 46,0 persen andikpas remaja memiliki kualitas komunikasi yang rendah dan 54,0 persen andikpas remaja memiliki kualitas komunikasi yang tinggi. Ratarata capaian kualitas komunikasi orang tuaremaja adalah 53,9 yang berarti andikpas remaja memiliki kualitas komunikasi yang masih tergolong rendah.

Hasil analisis menemukan bahwa 31,7 persen andikpas remaja memiliki tingkat self-esteem yang rendah dan 68,3 persen memiliki tingkat self-esteem yang tinggi, dengan rata-rata indeks self-esteem 57,1. Selanjutnya, sebanyak 47,6 persen andikpas remaja yang memiliki angka kenakalan remaja yang rendah dan 52,4 memiliki angka kenakalan remaja yang tinggi. Rata-rata indeks kenakalan remaja adalah 38,8.
Tabel 1 Sebaran tingkat kenakalan dengan nilai rataan jawaban tertinggi $(\geq 2)$

\begin{tabular}{|c|c|c|c|}
\hline Kenakalan remaja & $\mathrm{n}$ & $\%$ & $\begin{array}{l}\text { Rataan } \\
\text { jawaban }\end{array}$ \\
\hline $\begin{array}{l}\text { Kebut-kebutan di } \\
\text { jalan raya }\end{array}$ & 53 & 89,1 & 2,3 \\
\hline $\begin{array}{l}\text { Terlibat balapan } \\
\text { motor }\end{array}$ & 40 & 63,4 & 2,0 \\
\hline $\begin{array}{l}\text { Membeli minuman } \\
\text { beralkohol }\end{array}$ & 60 & 95,2 & 2,6 \\
\hline $\begin{array}{l}\text { Meminum minuman } \\
\text { beralkohol }\end{array}$ & 60 & 95,2 & 2,6 \\
\hline Merokok & 60 & 95,2 & 2,8 \\
\hline $\begin{array}{l}\text { Mengendarai motor } \\
\text { dalam keadaan } \\
\text { mabuk }\end{array}$ & 48 & 76,2 & 2,1 \\
\hline $\begin{array}{l}\text { Tawuran antar } \\
\text { kelompok }\end{array}$ & 49 & 77,8 & 2,1 \\
\hline Memukul orang lain & 55 & 87,3 & 2,1 \\
\hline $\begin{array}{l}\text { Menonton film } \\
\text { porno }\end{array}$ & 53 & 84,1 & 2,0 \\
\hline
\end{tabular}

Tabel 1 disajikan sebaran tingkat kenakalan dengan nilai rataan jawaban tertinggi $(\geq 2)$. Jawaban dengan nilai rataan tertinggi $\geq 2$ menunjukan mayoritas andikpas remaja pernah melakukan jenis kenakalan tersebut dengan intensitas kadang-kadang sampai sering. Kenakalan remaja dengan nilai rataan tertinggi yaitu merokok $(2,8)$, membeli dan meminum alkohol $(2,6)$ serta kebut-kebutan di jalan raya $(2,3)$. Selanjutnya, berdasarkan rataan nilai dimensi kenakalan pada Tabel 2, kenakalan yang banyak dilakukan oleh andikpas remaja adalah kenakalan yang berkaitan dengan alkohol dan narkoba sedangkan yang paling rendah adalah pada dimensi perusakan.

Bahasan yang menarik yang berkaitan dengan kenakalan remaja adalah lama hukuman (sebagai gambaran seberapa berat kasus yang menjerat responden ke LPKA). Menurut Undang-Undang Republik Indonesia Nomor 11 Tahun 2012 tentang Sistem Peradilan Pidana Anak (UU SPPA) Pasal 3, seorang anak tidak boleh dijatuhi hukuman mati atau hukuman seumur hidup. Lama hukuman yang dijalani andikpas remaja berada pada kisaran 7 bulan sampai 10 tahun dengan rata-rata lama hukuman 42,7 bulan atau sekitar 3,5 tahun. Lama hukuman ditentukan oleh kasus yang dilakukan andikpas remaja. Andikpas remaja dengan hukuman 7 bulan terlibat dalam kasus pencurian sedangkan andikpas remaja dengan lama hukuman 10 tahun terlibat dalam kasus pembunuhan yang dilakukan oleh perseorangan. Pengelompokan lama hukuman berdasarkan dari nilai rataan hukuman andikpas remaja secara keseluruhan. 
Tabel 2 Analisis deskriptif kenakalan remaja berdasarkan dimensi

\begin{tabular}{lrr}
\hline \multicolumn{1}{c}{$\begin{array}{c}\text { Dimensi } \\
\text { Kenakalan } \\
\text { Remaja }\end{array}$} & Min-Maks & Rata-rata $\pm S D$ \\
\hline Mencuri & $0,00-70,00$ & $22,54 \pm 20,31$ \\
Kejahatan di jalan & $0,00-83,00$ & $41,14 \pm 21,42$ \\
Alkohol\&narkoba & $9,00-100,00$ & $63,23 \pm 24,44$ \\
Agresi & $0,00-80,00$ & $36,51 \pm 23,29$ \\
$\begin{array}{l}\text { Perusakan } \\
\text { Kenakalan di }\end{array}$ & $0,00-80,00$ & $21,27 \pm 16,64$ \\
sekolah & $0,00-100,00$ & $48,15 \pm 24,88$ \\
Mengganggu & $0,00-80,00$ & $37,14 \pm 20,59$ \\
masyarakat & & \\
\hline
\end{tabular}

Uji hubungan antara tingkat kenakalan dan lama hubungan tidak menunjukan hubungan yang signifikan $(p>0,1)$. Tingkat kenakalan yang tinggi tidak menjamin anak terlibat kasus yang berat yang menyebabkan anak terjerat lama hukuman yang cukup lama. Hal ini disebabkan karena banyak faktor yang dapat memengaruhi pengambilan keputusan saat melakukan tindakan kejahatan.

\section{Hasil Uji Hubungan Antarvariabel}

Hasil penelitian menunjukkan tidak adanya hubungan yang signifikan antara variabel karakteristik remaja, karakteristik keluarga, dengan variabel komunikasi orang tua-remaja dan self-esteem. Selanjutnya dilakukan uji Korelasi Pearson antara komunikasi orang tuaremaja dan dimensinya dengan variabel selfesteem andikpas remaja (Tabel 3).

Hasil penelitian menunjukan bahwa terdapat hubungan positif sangat signifikan antara komunikasi orang tua-remaja dan self-esteem andikpas remaja $(r=0,524)$. Hal ini menunjukan bahwa semakin tinggi komunikasi orang tuaremaja maka semakin tinggi self-esteem yang dimiliki andikpas remaja sebelum masuk ke LPKA. Bila dilihat dari dimensi komunikasi, ditemukan adanya hubungan positif sangat signifikan antara keterbukaan dalam komunikasi dengan self-esteem remaja $(r=0,426)$. Temuan ini menunjukkan bahwa semakin terbuka komunikasi dalam suatu keluarga maka semakin tinggi self-esteem.

Tabel 3 Nilai koefisien korelasi antara komunikasi orang tua-remaja dan selfesteem andikpas remaja

\begin{tabular}{|c|c|}
\hline Variabel & $\begin{array}{l}\text { Koefisien Korelasi } \\
\text { Self-Esteem }\end{array}$ \\
\hline $\begin{array}{l}\text { Komunikasi } \text { Orang tua- } \\
\text { Remaja }\end{array}$ & $0,524^{* *}$ \\
\hline Keterbukaan & $0,426^{* *}$ \\
\hline Permasalahan & $-0,459^{* *}$ \\
\hline
\end{tabular}

Tabel 4 Nilai koefisien korelasi antara komunikasi orang tua-remaja, selfesteem, dan kenakalan andikpas remaja sebelum masuk LPKA

\begin{tabular}{cc}
\hline \multicolumn{1}{c}{ Variabel } & $\begin{array}{c}\text { Kenakalan } \\
\text { Remaja }\end{array}$ \\
\hline Komunikasi orang tua-remaja & $-0,341^{* *}$ \\
Keterbukaan & $-0,267^{*}$ \\
Permasalahan & $0,309^{*}$ \\
Self-esteem & $-0,422^{* *}$ \\
\hline Keterangan: ${ }^{*}$ nyata pada $\mathrm{p}<0.05 ;{ }^{* *}$ nyata pada $\mathrm{p}<0.01$
\end{tabular}

Hasil penelitian juga menemukan adanya hubungan negatif sangat signifiikan antara permasalahan dalam komunikasi dengan selfesteem remaja $(r=-0,459)$. Hal ini menunjukan bahwa semakin tinggi permasalahan dalam komunikasi antara orang tua-remaja maka semakin rendah self-esteem andikpas remaja sebelum masuk LPKA (Tabel 3).

Tabel 4 merupakan hasil uji Korelasi Pearson yang menunjukkan hubungan antara komunikasi orang tua-remaja dan dimensinya, self-esteem, dengan kenakalan andikpas remaja sebelum masuk LPKA. Hasil penelitian menunjukan bahwa terdapat hubungan negatif sangat signifikan antara self-esteem dan kenakalan andikpas remaja sebelum masuk LPKA $(r=-0,422)$. Hal ini menunjukan bahwa sebelum masuk LPKA, semakin tinggi selfesteem maka kenakalan remaja semakin menurun. Selain itu, terdapat hubungan negatif sangat signifikan antara komunikasi orang tua dan kenakalan andikpas remaja sebelum masuk LPKA $(r=-0,341)$. Hal ini menunjukan bahwa komunikasi yang baik antara orang tua dan andikpas remaja sebelum masuk LPKA akan menurunkan tingkat kenakalan remaja. Bila dilihat dari indikator pembangun kualitas komunikasi, terdapat hubungan negatif signifikasi antara keterbukaan dalam komunikasi dan kenakalan remaja $(r=-0,267)$. Artinya, semakin terbuka komunikasi dalam suatu keluarga maka semakin rendah kenakalan remaja. Sebaliknya, terdapat hubungan positif signifiikan antara permasalahan dalam komunikasi dan kenakalan remaja $(r=0,309)$. Hal ini menunjukan bahwa semakin tinggi permasalahan dalam komunikasi akan meningkatkan kenakalan remaja.

\section{PEMBAHASAN}

Santrock (2007) mengklasifikasikan kenakalan menjadi dua jenis meliputi indeks offenses dan status offenses. Indeks offenses merupakan kenakalan remaja yang termasuk tingkat kriminal, terlepas pelakunya adalah remaja atau orang dewasa. Kenakalan jenis ini 
meliputi perampokan, pembunuhan, perkosaan, dan penyerangan dengan kekerasan. Sementara itu, status offenses merupakan kenakalan yang dilakukan oleh remaja dengan melakukan hal yang seharusnya tidak dilakukan oleh anak seusianya. Kenakalan jenis ini meliputi kabur dari rumah, bolos, minum minuman keras, dan hubungan seksual. Berdasarkan hasil penelitian, andikpas remaja dalam penelitian ini terlibat melakukan kekanalan indeks offenses dan status offenses.

Berdasarkan hasil penelitian ditemukan bahwa kenakalan remaja berhubungan negatif dengan self-esteem remaja. Temuan ini sejalan dengan penelitian Rosenberg, Rosenberg, dan McCord (1978); Donnellan et al. (2005); Caldwell et al. (2006) yang menyatakan bahwa semakin tinggi self-esteem remaja maka kenakalan remaja semakin rendah. Pendapat lain dikemukakan oleh Christopher et al. (2007) dan Cheng (2014) yang menyatakan bahwa self-esteem memiliki pengaruh terhadap kenakalan remaja, akan tetapi tidak memiliki hubungan linear dengan kenakalan remaja melainkan memiliki hubungan curvilinier atau bentuk U. Artinya, pada remaja dengan nilai self-esteem rendah maka self-esteem memiliki hubungan negatif dengan kenakalan remaja. Sementara itu, pada remaja dengan kategori self-esteem tinggi maka self-esteem memiliki hubungan positif dengan kenakalan remaja. Pada penelitian ini, self-esteem dan kenakalan remaja memiliki hubungan linear yang negatif signifikan karena sebaran self-esteem andikpas remaja pada penelitian ini mayoritas berada kategori rendah dan sedang.

Teori Kaplan dalam Rosenberg, Rosenberg, dan McCord (1978) menjelaskan bahwa selfesteem memiliki peranan yang penting terhadap tingkat kenakalan. Remaja yang memiliki kerusakan self-esteem akan mencari cara untuk memperbaiki self-respect dengan melibatkan dirinya dengan kelompok yang menyimpang yang memiliki komitmen untuk ditolak seluruh masyarakat. Selanjutnya, Rosenberg, Rosenberg, dan McCord (1978) menyatakan bahwa terdapat pandangan lain tentang hubungan self-esteem dan kenakalan yang lebih menekankan pada reaksi sosial terhadap penyimpangan. Apapun penyebab awal kenakalan, kecaman masyarakat terhadap tingkat kenakalan dan internalisasi dari sikap orang lain terhadap individu yang melakukan kenakalan arahnya akan menyebabkan harga diri yang rendah. Akan tetapi dalam penelitian Rosenberg, Rosenberg, dan McCord (1978) ditemukan bahwa pembuktian lebih mengarah pada spekulasi Teori Kaplan, untuk keseluruhan contoh penelitian, dan ketika dipisahkan antar status ekonomi, hasil uji regresi menunjukan bahwa pengaruh self-esteem terhadap kenakalan lebih besar dari pada pengaruh kenakalan terhadap self-esteem, terutama pada ekonomi menengah ke bawah dimana dukungan sosial lebih besar daripada tuntutan atau kecaman sosial.

Hasil penelitian ini menunjukan bahwa terdapat hubungan negatif signifikan antara komunikasi orang tua-remaja dan kenakalan remaja. Selain berhubungan dengan selfesteem sebagai variabel individu, kenakalan remaja juga berhubungan dengan faktor keluarga. Temuan literatur menunjukkan bahwa keluarga memiliki efek tidak langsung dan parsial pada kecenderungan remaja untuk melakukan kejahatan karena mereka tidak dapat menyediakan jaringan sosial yang terorganisir, model peran, dan kontrol sosial bagi anak-anak mereka (Icli \& Coban, 2012). Moitra dan Mukherjee (2012) dalam penelitiannya menyatakan bahwa kepuasan remaja terhadap komunikasi orang tuanya menurunkan tingkat kenakalan remaja. Komunikasi memiliki efek interaksi yang signifikan secara alamiah. Hal ini mengindikasikan bahwa jika remaja menerima komunikasi yang memuaskan dari setidaknya satu dari orang tua maka dapat mengakibatkan rendahnya tingkat kenakalan. Bireda dan Pillay (2017) menyatakan bahwa komunikasi yang sehat dapat menunjukkan hubungan lebih baik secara keseluruhan antara orang tua dan remaja, yang dapat berfungsi sebagai faktor protektif untuk anak-anak terhadap perkembangan depresi.

Selanjutnya, penelitian ini menemukan adanya hubungan negatif signifikan antara keterbukaan komunikasi orang tua-remaja dengan kenakalan remaja yang artinya semakin tinggi keterbukaan dalam komunikasi akan menurunkan kenakalan pada remaja. Sebaliknya, terdapat hubungan positif signifikan antara permasalahan dalam komunikasi orang tua-remaja dengan kenakalan remaja. Hal ini menunjukan bahwa semakin tinggi permasalahan dalam komunikasi orang tua-remaja akan meningkatkan kenakalan remaja. Xiao, Li, dan Stanton (2011) menjelaskan bahwa keterbukaan dalam komunikasi dapat menurunkan kenakalan remaja. Ketika remaja merasa bahwa mereka dapat mengomunikasikan sudut pandang mereka 
kepada orang tua mendorong remaja lebih aktif dalam menangani masalah baik di dalam maupun di luar kehidupan keluarga sehingga dapat terhindar dari tingkat yang menyimpang. Keterbukaan orang tua mempermudah sosialisasi nilai kepada anak. Penelitian Pasaribu et al. (2013) menunjukkan bahwa sosialisasi yang buruk orang tua kepada anak dapat menurunkan karakter anak. Kuhlberg, Peña, dan Zayas (2010) dan Smokowski, Rose, dan Bacallao (2010) menemukan bahwa konflik dalam keluarga meningkatkan tingkat kenakalan remaja, konflik, dan hubungan yang tidak diinginkan orang tua dan remaja.

Penelitian ini juga menemukan bahwa komunikasi orang tua-remaja memiliki hubungan positif sangat signifikan terhadap self-esteem. Xiao, Li, dan Stanton (2011) menjelaskan bahwa keterbukaan dalam komunikasi meningkatkan self-esteem. Keterbukaan komunikasi pada remaja akan mendorong remaja lebih aktif dalam menangani masalah baik di dalam maupun di luar kehidupan keluarga, sehingga dapat meningkatkan self-esteem remaja (Jackson et al., 1998). Kernis, Brown, dan Brody (2000) dan Bulanda dan Majumdar (2009) menyatakan bahwa komunikasi orang tuaremaja yang berkualitas akan meningkatkan self-esteem remaja. Harris et al. (2015) menyatakan bahwa terdapat hubungan positif yang kuat antara kedekatan orang tua-remaja dengan self-esteem remaja.

Sebuah fakta menunjukan bahwa orang tua, terutama ketika hubungan dengan remajanya memiliki kualitas tinggi, dapat berfungsi sebagai penyangga terhadap tekanan remaja (Hazel et al., 2015). Komunikasi orang tuaremaja memiliki hubungan terhadap stabilisasi self-esteem remaja. Remaja dengan selfesteem yang tidak stabil memiliki frekuensi bicara lebih sedikit dengan orang tuanya. Selfesteem yang rendah dan tidak stabil berhubungan dengan presepsi anak terhadap orang tuanya yang sering mengeluarkan kata hinaan dan kritikan. Hal ini disebabkan karena anak memiliki sensitivitas terhadap evaluasi dan kritikan sehingga anak menjadi enggan berbicara dan kehilangan penghargaan terhadap dirinya sendiri. Remaja dengan selfesteem yang stabil dilaporkan terlibat dalam interaksi yang lebih intensif dengan orang tuanya (Kernis, Brown, \& Brody, 2000).

Keterbukaan memiliki hubungan positif signifikan dengan self-esteem remaja. Pengungkapan diri (keterbukaan) merupakan bagian dari proses komunikasi keluarga.
Dalam konteks perkembangan anak, terdapat perbedaan keterbukaan pada periode remaja dibandingkan dengan periode yang lain baik dalam derajat, topik, atau tingkat keterbukaan. Pengungkapan diri remaja dan orang tua dapat berubah sebagai akibat dari perkembangan remaja, khusus perubahan dalam perkembangan kognitif, fisik dan konsep diri (Norrell, 1984). Kesediaan orang tua untuk berinteraksi, baik ibu maupun ayah masingmasing memberikan kontribusi signifikan terhadap perkembangan self-esteem remaja. Kesediaan orang tua mencerminkan tingkat struktur dan bimbingan dalam kehidupan remaja yang berfungsi untuk membangun dan mempertahankan tingkat self-esteem yang lebih tinggi (Bulanda \& Majumdar, 2009).

Konflik memiliki hubungan negatif signifikan dengan self-esteem remaja. Sejalan dengan penelitian Kuhlberg, Peña, dan Zayas (2010) dan Smokowski, Rose, dan Bacallao (2010) yang menemukan bahwa konflik dalam keluarga berimplikasi pada rendahnya selfesteem remaja serta meningkatkan keterlibatan remaja dalam penggunaan narkoba. Orang tua yang cenderung menarik diri dari konflik berkaitan dengan self-esteem remaja yang rendah dan penggunaan obat terlarang yang tinggi. Hal ini menunjukan bahwa orang tua harus lebih responsif ketika remaja ingin membahas masalah meskipun permasalahan tersebut tidak terlalu penting untuk orang tua (Caughlin \& Malis, 2004).

Hasil penelitian ini menemukan bahwa kenakalan andikpas remaja yang dilakukan sebelum masuk LPKA tidak memiliki hubungan terhadap lama hukuman yang diterima anak. Tingkat kenakalan yang tinggi tidak menjamin anak terlibat kasus yang berat yang menyebabkan anak terjerat lama hukuman yang cukup lama. Hal ini disebabkan karena banyak faktor yang dapat memengaruhi pengambilan keputusan saat melakukan kenakalan, beberapa diantaranya adalah pengaruh teman sebaya, self-control, dan selfesteem remaja. Choon, Hasbullah, dan Ling (2013) dan Nisar et al. (2015) menyebutkan bahwa kelekatan teman sebaya (jika teman sebaya terlibat dalam tingkat kriminal) berpengaruh terhadap tingkat kriminal yang dilakukan remaja. Santrock (2003) dan Cobb (2001) menyatakan bahwa pada tahapan remaja terjadi perubahan antara remaja dan orang tuanya sehingga remaja lebih cenderung dekat dengan temannya. Hal ini diperburuk dengan self-esteem dan self-control yang rendah. Selain itu, self-control remaja juga memiliki kontribusi terhadap keputusan remaja 
untuk melakukan kejahatan. Boisvert et al. (2012) menyebutkan bahwa kontrol diri yang rendah akan memiliki kecenderungan untuk meningkatkan tingkat kenakalan remaja. Remaja yang memiliki self-esteem dan selfcontrol akan mencari cara untuk memperbaiki self-respect dengan melibatkan dirinya dengan kelompok yang menyimpang (Rosenberg, Rosenberg, \& McCord, 1978).

Penelitian ini memiliki banyak keterbatasan yaitu perlunya alat ukur yang lebih sensitif untuk menganalisis komunikasi ayah dan ibu secara khusus. Selanjutnya, pengambilan data komunikasi orang tua-remaja hanya menggunakan presepsi anak saja sehingga masih memungkinkan adanya bias dan ketidaksesuaian. Perlu dilakukan penelitian lanjutan untuk mengakomodasi presepsi komunikasi orang tua-remaja dari sudut pandang orang tua.

\section{SIMPULAN DAN SARAN}

Hasil penelitian menunjukan self-esteem yang tinggi dan komunikasi orang tua-remaja yang baik berhubungan dengan menurunnya tingkat kenakalan andikpas remaja sebelum masuk LPKA. Remaja yang memiliki self-esteem yang tinggi dan memiliki komunikasi yang baik dengan orang tuanya dan akan terhindar dari kenakalan remeja. Selain itu, komunikasi yang terjalin dengan baik antara orang tua dan remaja terbukti berhubungan dengan meningkatnya self-esteem andikpas remaja sebelum masuk LPKA. Bila dijabarkan dari dimensi komunikasi, diketahui bahwa keterbukaan dalam komunikasi orang tuaremaja dapat meningkatkan self-esteem dan menurunkan kenakalan pada andikpas remaja sebelum masuk LPKA. Sebaliknya, permasalahan dalam komunikasi akan menurunkan self-esteem dan meningkatkan perilaku kenakalan pada pada andikpas remaja sebelum masuk LPKA.

Berdasarkan penelitian yang dilakukan, hendaknya orang tua menerapkan komunikasi positif dengan anak. Orang tua hendaknya tidak menciptakan jarak dalam berkomunikasi dengan remaja sehingga remaja bisa lebih terbuka untuk menyampaikan keinginan dan permasalahan yang sedang dirasakannya. Hal ini akan memfasilitasi terciptanya interaksi yang baik dan meningkatkan kepercayaan remaja terhadap orang tuanya. Selain itu, orang tua harus memberikan pengawasan terhadap pergaulan remaja, mengenai siapa temannya, mengetahui aktivitas yang dilakukanya, mengawasi apa yang diakses oleh anak. Untuk LPKA diharapkan mampu mengadakan program-program yang mampu mengembalikan self-esteem agar anak kembali merasa dirinya berharga, dan memiliki perencanaan untuk meneruskan hidup setelah keluar dari LPKA. Hal ini dapat dilakukan mengadakan kegiatan achievment motivation training dan memberikan pendidikan karakter serta membekali andikpas dengan kemampuan berwirausaha. Untuk memperluas keilmuan, perlu dilakukan penelitian lanjutan untuk mengakomodasi presepsi komunikasi orang tua-remaja dari sudut pandang orang tua. Selain itu, pada penelitian ini ditemukan bahwa self-esteem memiliki pengaruh terhadap kenakalan remaja. Berdasarkan kerangka pemikiran lain maka penelitian ini menyarankan perlunya diadakan penelitian lanjutan untuk mengukur apakah kenakalan remaja juga memiliki pengaruh terhadap selfesteem.

\section{DAFTAR PUSTAKA}

Barnes, H. L. \& Olson, D. H. (1982). Parentadolescent communication scale. In Olson D. H., McCubbin H. I., Barners H., Larsen A., Muxen M., \& Wilson M. (Eds.), Family inventories: Inventories used in a nationel survey of families across the family life cycle (pp. 33-48). ST Paul: Family Social Science: University of Minnesota.

Berlianti, D., Vityala, A., Hastuti, D., Sarwoprasodjo, S., \& Krisnantuti, D. (2016). Ada apa dengan komunikasi orang tua-remaja?: pengaruhnya terhadap agresivitas remaja pada sesama. Jurnal IImu Keluarga dan Konsumen, 9(3), 183-194.

Bireda, A. D., \& Pillay, J. (2017). Perceived parent-child communication and wellbeing among Ethiopian adolescents. International Journal of Adolescence and Youth, 1-9.

Bulanda, R. E., \& Majumdar, D. (2009). Perceived parent-child relations and adolescent self-esteem. Journal of Child and Family Studies, 18(2), 203-212.

Boisvert, D., Wright, J. P., Knopik, V., \& Vaske, J. (2012). Genetic and environmental overlap between low selfcontrol and delinquency. Journal of Quantitative Criminology, 28(3), 477507. 
Caldwell, R. M., Beutler, L. E., Ross, S. A., \& Silver, N. C. (2006). Brief report: An examination of the relationships between parental monitoring, self-esteem and delinquency among Mexican American male adolescents. Journal of Adolescence, 29(3), 459-464.

Carroll, A., Durkin, K., Houghton, S., \& Hattie, J. (1996). An adaptation of mak's selfreported delinquency scale for Western Australian adolescents. Australian Journal of Psychology, 48(1), 1-7.

Caughlin, J. P., \& Malis, R. S. (2004). Demand/withdraw communication between parents and adolescents: Connections with self-esteem and substance use. Journal of Social and Personal Relationships, 21(1), 125-148.

Cheng, C. (2014). The predictive effects of self-esteem, moral self, and moral reasoning on delinquent behaviors of Hong Kong young people. International Journal of Criminology and Sociology, 3, 133-145.

Choon, L. J., Hasbullah, M., \& Ling, W. S. (2013). Parental attachment, peer attachment, and delinquency among adolescents in Selangor, Malaysia. Asian Social Science, 9(15), 214-219.

Cobb, N. J. (2001). Adolescence: continuity, change, and diversity fourth edition. New York, NY: Mayfield Publishing company.

Coopersmith, S. (1967). The antecendents of self-esteem. San Fransisco, US: W. H. Freeman and Company.

Christopher, T. B., Sarah, J.G., Kristy, K.A., \& Jessica, D. P. (2007). The relations among narcissism, self-esteem, and delinquency in a sample of at-risk adolescents. Journal of Adolescence, 30 ,

933-942.

doi:10.1016/j.adolescence.2006.12.003.

[Ditjenpas]. Direktorat Jendral Pemasyarakatan. (2015). Laporan UPT lembaga khusus anak kelas II Bandung Kanwil Jawa Barat 2015. Diambil dari http://smslap.ditjenpas.go.id.

Donnellan, M. B., Trzesniewski, K. H., Robins, R. W., Moffitt, T. E., \& Caspi, A. (2005). Low self-esteem is related to aggression, antisocial behavior, and deliquency.
American Psychological Society, 16(4), 328-335.

Firdanianty, Lubis, D. P., Puspitawati, H., \& Susanto D. (2016). Komunikasi remaja dengan ayah masih minim : Studi pada siswa SMA di Kota Bogor. Jurnal IImu Keluarga dan Konsumen, 9(2), 124-135.

Gunawan, H. (2013). Jenis pola komunikasi orang tua dengan anak perokok aktif di Desa Jembayan Kecamatan Loa Kulu Kabupaten Kutai Kartanegara. Ejournal IImu Komunikasi, 1(3), 218-233.

Gunarsa, S., \& Gunarsa, Y. (2004). Psikologi praktis: anak, remaja dan keluarga. Jakarta, ID: BPK Gunung Mulia.

Harris, M. A., Gruenenfelder-Steiger, A. E., Ferrer, E., Donnellan, M. B., Allemand, M., Fend, H., \& Trzesniewski, K. H. (2015). Do parents foster self-esteem? testing the prospective impact of parent closeness on adolescent selfesteem. Child Development, 86(4), 9951013.

Hazel, N., Oppenheimer, C., Technow, J., Young, J., \& Hankin, B. (2015). Parent relationship quality buffers against the effect of peer stressors on depressive symptoms from middle childhood to adolescence. Dev. Psychol., 50(8), 2115-2123. doi: 10.1037/a0037192.

Icli, T. G., \& Çoban, S. (2012). A study on the effects of family and delinquent peers on juvenile delinquency in Turkey. Advances in Applied Sociology, 2(1), 6672.

Jackson, S., Bijstra, J., Oostra, L., \& Bosma, H. (1998). Adolescents' perceptions of communication with parents relative to specific aspects of relationships with parents and personal development. Journal of Adolescence, 21(3), 305-322.

Kartono, K. (2008). Patologi sosial 2: kanakalan remaja. Jakarta, ID: Raja Grafindo Persada.

Kernis, M.H., Brown, A.C., \& Brody, G. H. (2000). Fragile self-Esteem in children and its associations with perceived patterns of parent-child communication. Journal of Personality, 68(2). 225-252. 
Kuhlberg, J. A., Peña, J. B., \& Zayas, L. H. (2010). Familism, parent-adolescent conflict, self-esteem, internalizing behaviors and suicide attempts among adolescent Latinas. Child Psychiatry \& Human Development, 41(4), 425-440.

Moitra, T., \& Mukherjee, I. (2012). Parentadolescent communication and delinquency: a comparative study in Kolkata, India. Eur J Psychol, 8(1): 7494.

Ngale, I. F. (2009). Family structure and juvenile delinquency: correctional centre Betamba, centre province of Cameroon. Internet Journal of Criminology, 1-19. Diambil dari https://pdfs.semanticscholar.org/aa23/e0 7e18f4c9d6e272ac620b521f4a436c1718 .pdf?_ga=2.234739678.1938675477.149 7930099-1351896934.1497930099.

Nisar, M., Ullah, S., Ali, M., \& Alam, S., (2015). Juvenile delinquency: The Influence of family, peer and economic factors on juvenile delinquents. Applied Science Reports, 9(1), 37-48.

Norrell, J. E., (1984). Self-disclosure: Implications for the study of parentadolescent interaction. Journal of Youth and Adolescence, 13(2), 163-178.

Odgers, C. L., Caspi, A. C., Russell, M. A., Sampson, R. J., Arseneault, L., \& Moffitt, T. E. (2012). Supportive parenting mediates neighborhood socioeconomic disparities in children's antisocial behavior from ages 5 to 12 . Development and Psychopathology, 24(3), 705-721. doi:10.1017/S0954579412000326.

Pasaribu, R. M., Hastuti, D., \& Alfiasari. (2013). Gaya pengasuhan permisif dan rendahnya sosialisasi nilai dalam keluarga berisiko terhadap penurunan karakter remaja. Jurnal IImu Keluarga dan Konsumen, 6(3), 163-171.

Puspitawati, H. (2006). Pengaruh faktor keluarga, lingkungan teman dan sekolah lanjut tingkat atas di Kota Bogor
(Disertasi). Institut Pertanian Bogor, Bogor, Indonesia.

Putra, N. F. P. (2013). Peranan komunikasi interpersonal orang tua dan anak dalam mencegar tingkat seks pranikah di SMA negeri 3 Samarinda kelas XII. Ejournal IImu Komunikasi, 1(3), 35-53.

Santrock, J. W. (2003). Adolesence perkembangan remaja. Ed. Ke-6. Penerjemah: Adelar, S., Saragih S.; Editor: Kristiadji, Sumiharti, Y., Jakarta, ID: Erlangga.

Santrock, J. W. (2007). Perkembangan anak, edisi ketujuh, jilid dua. Penerjemah: Rachmawati, M.; Kuswanti, A. Jakarta, ID: Erlangga.

Sarwono, S. W. (2012). Psikologi remaja. Jakarta, ID: PT Rajagrafindo Persada.

Smokowski, P. R., Rose, R. A., \& Bacallao, M. (2010). Influence of risk factors and cultural assets on Latino adolescents' trajectories of self-esteem and internalizing symptoms. Child Psychiatry \& Human Development, 41(2): 133-155.

Rosenberg, M. (1965). Society and the adolescent self-image. Princeton, $\mathrm{NJ}$ : Princeton University Press.

Rosenberg, F. R., Rosenberg, M., \& McCord, J. (1978). Self-esteem and delinquency. Journal of Youth and Adolescence, 7(3), 279-294.

Xiao, Z., Li X., \& Stanton, B. (2011). Perception of parent-adolescent communication within families: It is a matter of perspective. Psychology, Health, and Medicine. 16(1), 53-65. doi:10.1080/13548506.2010.521563.

Wan, Y. Y. T. (2012). Cognitive and emotional determinants of delinquent behaviour. SS Student E-Journal, 1, 42-59.

Youngs, B. B. (1991). How to develop selfesteem in your child : 6 vital ingredients. New York, US: Ballantine Books. 